\title{
The genus Chironius (Serpentes, Colubridae) in Paraguay: composition, distribution, and morphology
}

\author{
Pier Cacciali1 ${ }^{1,2,}$, Hugo Cabral ${ }^{1,3}$ \\ ${ }^{1}$ Instituto de Investigación Biológica del Paraguay, Del Escudo 167, Asunción, Paraguay. \\ 2 Senckenberg Forschungsinstitut und Naturmuseum, Senckenberganlage 25, 60325 Frankfurt am Main, \\ Germany. \\ ${ }^{3}$ Guyra Paraguay, Gaetano Martino 215, Asunción, Paraguay. \\ * Correspondence: Senckenberg Forschungsinstitut und Naturmuseum. Senckenberganlage 25, 60325 Frank- \\ furt a. M., Germany. Phone: +49 697542 1563, E-mail: pcacciali@senckenberg.de
}

Received: 3 July 2014; returned for review: 10 November 2014; accepted 27 May 2015.

Chironius is a genus of slender snakes adapted to a diurnal and arboreal life style, and is distributed from Honduras to Uruguay inhabiting different environments. Five species are present in Paraguay: $C$. bicarinatus, C.exoletus, C. flavolineatus, C. maculoventris, and C. quadricarinatus. In this work, we provide data on distribution, coloration, and morphological variation of 20 Paraguayan specimens housed in scientific collections. Our results fit with known parameters for the species referred in literature. A conclusion of this work is that, based on distribution and ecological preferences of the species in the region, Paraguay is poorly sampled. Here we extend the known pholidosis range of ventral scale for females of C. bicarinatus (154-170), and for C. maculoventris (143-157 for females and 154-161 for males ), and the range of subcaudal scales for males of C. maculoventris (90-125), and females of C. quadricarinatus (91-123).

Key words: morphological variation; Neotropical region; pholidosis; sexual dimorphism.

El género Chironius (Serpentes, Colubridae) en Paraguay: diversidad, distribución y morfología. Chironius es un género de serpientes gráciles adaptadas a un modo de vida diurno y arborícola, que se distribuye desde Honduras hasta Uruguay habitando diferentes ambientes. En Paraguay están presentes cinco especies: C. bicarinatus, C. exoletus, C. flavolineatus, C. maculoventris y C. quadricarinatus. En este trabajo se aportan datos acerca de la distribución, coloración y variación morfológica de 20 especímenes de Paraguay depositados en colecciones científicas. Los resultados se ajustan a los parámetros conocidos para las especies referidos en la literatura. Una de las conclusiones del presente trabajo es que, de acuerdo a la distribución y a las preferencias ecológicas de las especies a nivel regional, Paraguay está pobremente muestreado. Ampliamos los rangos conocidos de folidosis en lo referente a escamas ventrales para hembras de C. bicarinatus (154-170) y para C. maculoventris (143-157 para hembras y 154-161 para machos), y en lo relativo a escamas subcaudales para machos de C. maculoventris (90-125) y hembras de C. quadricarinatus (91-123).

Key words: dimorfismo sexual; rango de folidosis; región Neotropical; variación .

Chironius is a colubrid snake genus of slender aspect with head well differentiated from the body, rounded pupil, and aglyph dentition with maxillae holding 25 to 46 
teeth (Chippaux, 1986). These snakes have both arboreal and diurnal habits (MARTINS et al., 2008) and thus show some anatomical adaptations for that lifestyle such as long tail, big eyes, and the ability to move quickly to allow themselves to thrive in these types of environments (CEI, 1993). Although Pinto et al. (2008) and Palmuti et al. (2009) stated that is a snake specialized in the ingestion of anurans, YАNOSKY et al. (1996) documented this genus also feeding on lizards.

The genus has a wide distribution range, from Honduras in Central America to northern Argentina, Uruguay and southern Brazil in South America (Tipton, 2005), inhabiting areas of forest, grassland and open xerophytic environments. Snakes of this genus are usually poorly known because they appear infrequently in herpetological inventories (e.g. STRUssMANN \& SAZIMA, 1993; YANOSKY et al., 1996; Marques et al., 2000; Palmuti et al., 2009) being its occurrence lower in dry than in rainy seasons (MARQues et al., 2000).

Кок (2010) recognized the presence of 21 species belonging to this genus. LiNNAEus (1758) described the three first species: C. carinatus, C. exoletus, and C. fuscus under the genus Coluber. Fitzinger (1826) described the genus Chironius to include aglyph colubrid snakes with 10 or 12 scale rows around the body and simple hemipenis. Dixon et al. (1993) provided additional synapomorphies. In a recent study, Hollis (2006) confirmed the strong monophily of the group, and also provided information improving the systematic of the genus, rising to specific status some taxa previously assigned to subspecies.

In Paraguay, three species have been traditionally considered, Chironius bicarinatus, C. flavolineatus, and C. quadricarinatus (Aquino et al., 1996; Giraudo, 2001; Моtтe et al., 2004; CACCIALI, 2009), with two subspecies of C. quadricarinatus, C. q. quadricarinatus and C. q. maculoventris, that were further raised to the species status by HoLLis (2006). Additionally, C. laevicollis was also documented in Paraguay (specimen ZIMH 677 of the Zoologisches Institut und Zoologisches Museum of Hamburg) by Dixon et al. (1993). Nevertheless, those same authors doubt about the validity of that record, saying that there would be a mistake in the locality data, and then is not considered a valid species for the herpetofauna of Paraguay.

Dixon et al. (1993) presented detailed information about the morphology of the species of this genus. Since then, Giraudo (2001) updated the morphological information for specimens from Argentina, and Carreira et al. (2005) and Carreira \& Maneyro (2013) did similar revisions for Uruguay. In this work, we review the genus Chironius from Paraguay, providing data about color variation, pholidosis, and distribution of each species, indicating their habitat preferences. We document new pholidosis ranges for some species.

\section{Materials and Methods}

For this work, we examined 20 specimens housed in the following collections: British Museum of Natural History (BMNH - London, England), biological collection of the Itaipí Museum-Reptiles (CBMI-R - Hernandarias, Alto Paraná, Paraguay), zoological collection of the School of Exact and Natural Sciences, National University of Asunción (CZ - San 
Table 1: List of examined specimens with indication of their reported origin, sex (F: female, M: male), and some pholidosis data. VENT: ventral scales, SC: subcaudal scales. D: damaged specimen, scale counting not possible. Refer to text for details about the museum collection codes. Numbers in bold indicate values out of the previously known pholidosis ranges. The asterisk $\left(^{*}\right)$ indicates the holotype for the corresponding species.

\begin{tabular}{|c|c|c|c|c|c|c|}
\hline Species & Specimen & Sex & Reported origin & VENT & SC & $\begin{array}{c}\text { SC/ } \\
\text { VENT }\end{array}$ \\
\hline \multirow[t]{2}{*}{ C. bicarinatus } & CBMI-R 60 & F & Alto Paraná & 168 & 127 & 0.756 \\
\hline & USNM 253552 & $\mathrm{~F}$ & Itapúa: El Tirol & 170 & 134 & 0.788 \\
\hline C. exoletus & CBMI-R 86 & M & Alto Paraná & 156 & 150 & 0.962 \\
\hline \multirow[t]{3}{*}{ C. flavolineatus } & BMNH 85.9.1.9 & $\mathrm{F}$ & Paraguay & 159 & 126 & 0.792 \\
\hline & MNHNP 5201 & M & $\begin{array}{l}\text { Amambay: Parque Nacional Cerro } \\
\text { Corá }\end{array}$ & 146 & 130 & 0.890 \\
\hline & USNM 342095 & M & $\begin{array}{l}\text { Amambay: Parque Nacional Cerro } \\
\text { Corá }\end{array}$ & 148 & 138 & 0.932 \\
\hline \multirow[t]{9}{*}{ C. maculoventris } & MNHNP 3167 & $\mathrm{~F}$ & $\begin{array}{l}\text { Presidente Hayes: Hacienda Tin- } \\
\text { funqué }\end{array}$ & 157 & 109 & 0.694 \\
\hline & MNHNP 5226 & $\mathrm{~F}$ & Boquerón: Route IX, km 472 & 154 & 103 & 0.669 \\
\hline & MNHNP 5480 & F & Rancho Carandá & 143 & 108 & 0.755 \\
\hline & CZ 512 & M & Rancho Carandá & 155 & 115 & 0,742 \\
\hline & MNHNP 2504 & M & Alto Paraguay: Madrejón & 154 & 90 & 0.584 \\
\hline & MNHNP 2505 & M & Alto Paraguay: Madrejón & 155 & 109 & 0.703 \\
\hline & MNHNP 3782 & M & Route IX, km 343 & 157 & 97 & 0.618 \\
\hline & MNHNP 9252 & M & Paraguay & 153 & $\mathrm{D}$ & - \\
\hline & MNHNP 10016 & M & Pozo Colorado & 161 & 122 & 0.758 \\
\hline \multirow[t]{5}{*}{ C. quadricarinatus } & MNHNP 2503 & $\mathrm{~F}$ & Central: Asunción & 154 & 91 & 0.591 \\
\hline & MNHNP 5479 & $\mathrm{~F}$ & Concepción: Rancho Z & 151 & 119 & 0.788 \\
\hline & MNHNP 11699 & $\mathrm{~F}$ & Laguna Blanca & 151 & 120 & 0.795 \\
\hline & MNHNP 10900 & M & San Pedro: Estancia Pedernal & 144 & 129 & 0.896 \\
\hline & USNM 5813* & M & Paraguay & 148 & $>80$ & - \\
\hline
\end{tabular}

Lorenzo, Paraguay), National Museum of Natural History of Paraguay (MNHNP San Lorenzo, Paraguay), and United States National Museum (USNM - Washington
DC, USA). The list of examined specimens is shown in Table 1.

Meristic characters of cephalic pholidosis were preocular scales (PRO), postocu- 
lar scales (POO), anterior and posterior temporal scales (TEMP), supralabial scales indicating between parentheses which ones are in contact with the orbit (SL), and infralabial scales indicating between parentheses which ones are in contact with genial scales (IL). Paired structures are shown in left / right order. Damage in pholidosis is indicated with a " $\mathrm{D}$ ".

In body pholidosis we counted the scale rows around the mid-body, identifying also reduction in one-head length behind the neck, and one-head length before the vent (DOR), ventral scales (VENT) following Dowling (1951), and subcaudal scales (SC) without including the pair of precloacal plates nor the apical tip. When hemipenis were not everted, sexual identification was made by an incision in the tail.

Because the low number of Paraguayan specimens, it was not possible to apply a statistical test to determine significant differences among species.

Coloration was described upon field notes and photographs of alive animals, with exception of $C$. bicarinatus, for which coloration description was based only in preserved specimens.

A distribution map of each species was created, based on the Paraguayan ecoregions, in order to know the ecological and ecoregional affinities of each species. With this purpose, we used the map of ecoregions based on Dinerstein et al. (1995). Plots of distribution maps were done using ArcGis 10.

\section{Results}

Chironius bicarinatus (Wied, 1820). Two females. DOR 12 / 12 / 10 and 13 / 12 / 12,
VENT 168-170, and SC 127-134; ratios SC / VENT 0.75-0.78; PRO and POO always $1 /$ 1 and $2 / 2$, respectively; TEMP $1+1 / 1+1$ and $2+1$ / 2 + 2; SL 9 (4-6); IL usually 10 (1 -6) except for the left side of female specimen USNM 253552, where it was 9 (1-5). Four to five dorsal scales keeled. Coloration of adult (CBMI-R 60) and juvenile (USNM 253552) specimens fits with those described by Dixon et al. (1993) and GirauDo (2001). The species is distributed in Alto Paraná and Itapúa Departments, being restricted to the Alto Paraná Atlantic Forest (Fig. 1). Bertoni (1939) recorded this taxon in Puerto Bertoni, and Giraudo (2001) in Ciudad del Este, both in Alto Paraná Department. In this area occur the highest and most moist forests of Paraguay, following this ecoregion the course of Paraná River.

Chironius exoletus (Linnaeus, 1758). One male with damaged head. DOR 12 / 12 / 08, VENT 156, and SC 150; ratio SC / VENT 0.96; PRO 1 / 1, and POO 2 / 2; TEMP, SL, and IL damaged. Two paravertebral rows of keeled scales. Even when the specimen is damaged and dehydrated, it is possible to see the coloration, which coincides with color description of GIRAUDo (2001). The only specimen known came from Itaipú Reserve in Alto Paraná Atlantic Forest (Fig. 1).

Chironius flavolineatus (Jan, 1863). One female and two males. DOR $12 / 10 / 10$ in the female and 12 / 12 / 08 and 12 / 12 / 10 in males, VENT 146-159, and SC 126-138; ratios SC / VENT 0.89-0.93 in males and 0.79 in the female; PRO and POO always $1 / 1$ and 2 / 2, respectively; TEMP always $1+1$; SL usually 9 (4-6) except for the left side of specimen USNM 342095, where it 


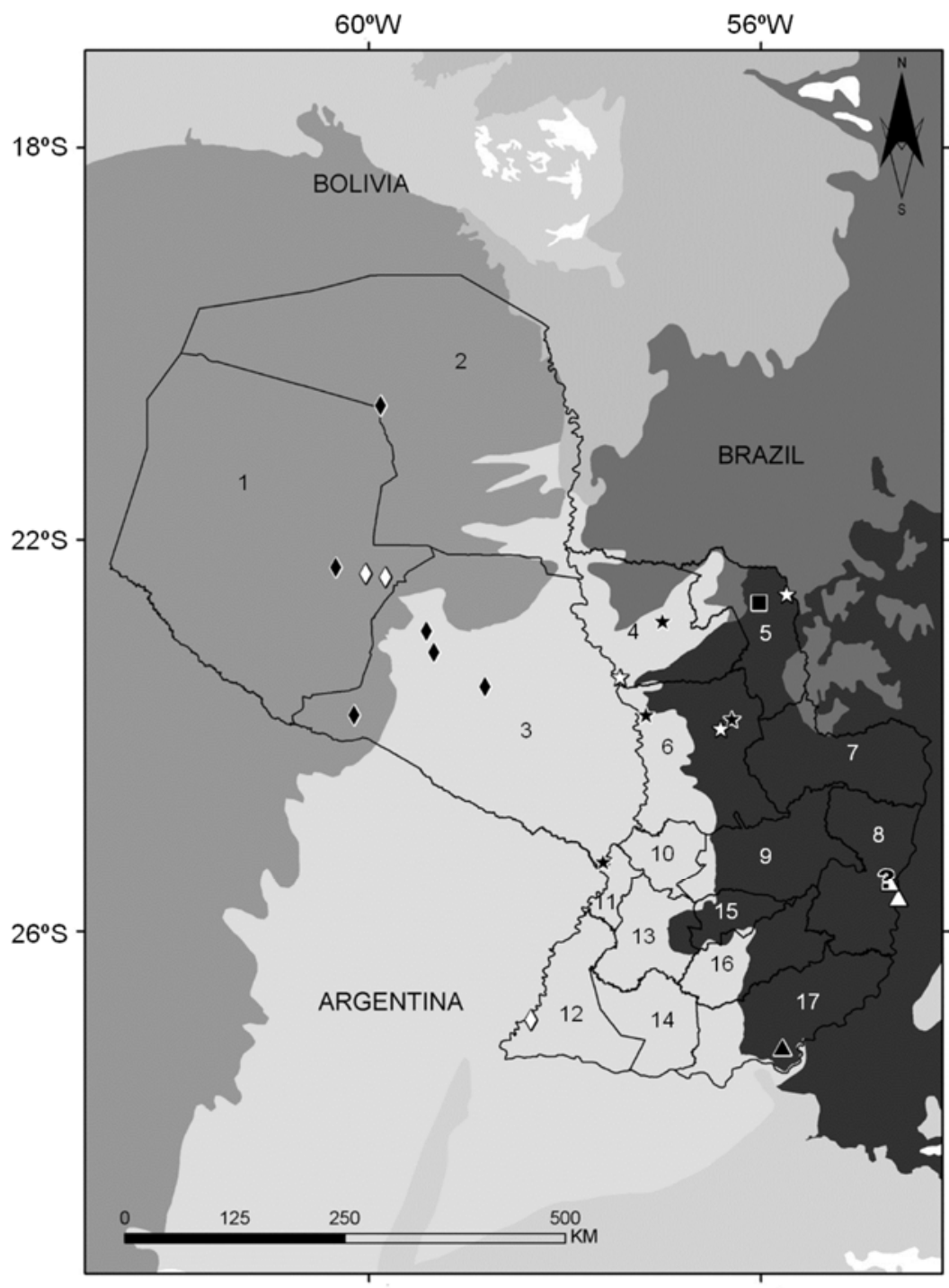

\section{Ecoregions}

Atlantic forest

Cerrado

Dry Chaco

Pantanal

Humid Chaco

\section{Departments}

1 Boquerón

2 Alto Paraguay

3 Presidente Hayes

4 Concepción

5 Amambay

6 San Pedro

7 Canindeyú

8 Alto Paraná

9 Caaguazú

10 Cordillera

11 Central

12 Ñeembucú

13 Paraguari

14 Misiones

15 Guairá

16 Caazapá

17 Itapúa

Figure 1: Political and ecoregional map of Paraguay, showing locality records of Chironius bicarinatus (triangles), C. flavolineatus (square), C. maculoventris (diamonds), and C. quadricarinatus (stars). White symbols represent literature records and black symbols represent specimens examined in the present study. The question mark represents the Alto Paraná record for C. bicarinatus and $C$. exoletus.

was 8 (3-5); IL 9 (1-6) / 9 (1-6) in males and $10(1-5) / 10(1-5)$ in the female. Coloration is coincident with literature descriptions (Dixon et al., 1993). Related to Cerrado ecore- gion in the northeast area of Oriental Region of Paraguay (Amambay Department) (Fig. 1). This environment is dominated by natural grasslands with forests in island 
patches or in gallery along streams.

Chironius maculoventris Dixon, Wiest \& Cei, 1993. Three males and six females. DOR 12-13-14 / 12 / 10, VENT 143-161, and SC 90-122; ratios SC / VENT 0.58-0.75 in males and 0.66-0.75 in females; PRO and POO always $1 / 1$ and 2 / 2, respectively; TEMP usually $1+2$, but sometimes $1+2$ / $2+2(\mathrm{CZ} 512), 2+2 / 1+2$ (MNHNP 3783), and $2+2 / 2+2$ (MNHNP 3167, 9252); SL highly variable: 7 (4-5) / 7 (4-5) (MNHNP 9252), 7 (4-5) / 8 (4-5) (CZ 512), 8 (4-5) / 8(4 -5) (MNHNP 3782, 5480), 8 (4-5) / 9 (5-6) (MNHNP 2504), 9 (5-6) / 8 (4-5) (MNHNP 10016), 9 (5-6) / 9 (5-6) (MNHNP 2505, 3167), and 9 (6-7) / 8 (4-5) (MNHNP 5226). IL 10 (1-6), except MNHNP $3782-11$ (1-6) / D-, MNHNP 5226 -8 (1-4) / 9 (1-5) -, and MNHNP 5480 -9 (1-6) / 9 (1-6) -. Coloration fits rather well with previous color descriptions (Dixon et al., 1993) except for the brown color on the top of the head (olive color in literature). Black stripe on postocular and temporal areas reaches the neck. The iris is black. Our Paraguayan records are in Dry Chaco (Fig. 1), including bibliographic records from Loma Plata (Dixon et al., 1993) and Filadelfia (Ziegler et al., 2002), both in Boquerón Department. This ecoregion is composed by thorny vegetation (bromeliads, cactus) and the herbaceous stratus is almost absent. Nevertheless, some literature records also indicate its presence in Paraguayan and Argentinean Humid Chaco (Giraudo \& ContreRAs, 1994; Giraudo, 2001).

Chironius quadricarinatus (Boie, 1827). Three females and two males. DOR 12 / $12 / 10$ and $14 / 12 / 10$, but specimen MNHNP 10900 with 12 / 12 / 08; VENT 144 -154, and SC 91-129; ratios SC / VENT 0.89 in the only male for which it was calculated and 0.59-0.79 in the females; PRO and POO always 1 / 1 and 2 / 2, respectively; TEMP always $1+2$; SL usually 9 (5-6), except left side of MNHNP 10900 , where it was 8 (4-5), and both sides of MNHNP 11699, where it was 8 (5-6); IL 10 (1-6), except MNHNP 5479, where it was 11 (1-7) / 11 (1-7); the IL of MNHNP 10900 was damaged. Head and neck reddish brown, and iris black; the rest of the coloration fits with the known parameters for the species (Dixon et al., 1993). In Paraguay, this species is associated with Paraguay River Basin, in Humid Chaco ecoregion, reaching a patch of Cerrado in Laguna Blanca (San Pedro). Humid Chaco is seasonal flooding, with forests showing a mix of components between Dry Chaco and Atlantic Forests. The environment in Laguna Blanca resembles a Cerrado ecoregion habitat. Dixon et al. (1993) gave additional records for Carumbé (San Pedro Department), Concepción (Concepción Department), and Pedro Juan Caballero (Amambay Department), being the latter in Cerrado (Fig. 1).

\section{Discussion}

Because the small sample size, it was not possible to test whether the differences in pholidosis ranges, according to sexual dimorphism, were significant. With these few samples, we observed that the ranges of ventral and subcaudal scales do not overlap between males and females of $C$. flavolineatus and C. quadricarinatus (Table 1). However, Dixon et al. (1993), who had a bigger sample size, recorded overlap among ventral scale numbers of those five species in both sexes, showing females of C. flavolineatus and C. maculoventris the same 
pholidosis range. Subcaudal scales showed no overlap between females of $C$. bicarinatus and C. maculoventris, and between males of C. maculoventris and those of either C. exoletus or C. flavolineatus (Dixon et al. 1993).

Ventral scales of female C. bicarinatus showed the highest value for this pholidotic parameter, whereas males of $C$. quadricarinatus had the lowest, which coincides with the observations of Dixon et al. (1993). With respect to subcaudal scales, females of C. bicarinatus had the highest number among females, being this value even higher than that of males of C. maculoventris and C. quadricarinatus. This same pattern was also observed by Dixon et al. (1993). The male of C. exoletus had the highest number of subcaudal scales, with a value that was even higher than the number of ventral scales of male C. flavolineatus and C. quadricarinatus. Dixon et al. (1993) presented a range of subcaudal scales for C. bicarinatus males between 125 and 157, which were also the highest values recorded in that study. Chironius maculoventris and females of C. quadricarinatus had the lowest number of subcaudal scales, a similar pattern than that observed in the results of Dixon et al. (1993).

The difference between SC and VENT was highest in C. maculoventris, being rather small in males of the remaining species (ratios over 0.89). This motivated the absence of apparent sexual dimorphism in SC / VENT ratio in C. maculoventris. The SC / VENT ratio in both sexes of C. maculoventris was below 0.76, a range similar to that shown by females of the rest of species (Table 1).

Marques \& SAzima (2003) stated that ontogenetic color changes are common for Chironius, arguing that even C. flavolineatus color changes ontogenetically, contrary to what Dixon et al. (1993) had claimed. Besides ontogenetic color changes, the presence of a light vertebral stripe is rather consistent in hatchlings, juveniles or adults of C. $b i$ carinatus and C. flavolineatus (Dixon et al., 1993; Carreira \& Maneyro, 2013), and our observations confirmed that.

Coloration also has implications in phylogenetic structure. Chironius maculoventris and C. quadricarinatus are the most similar in dorsal color pattern, and they belong to sister clades, while C. bicarinatus and $C$. flavolineatus are nested in different clades (Hollis, 2006). Dixon et al. (1993) already stated that ventral coloration differs substantially between C. quadricarinatus and C. maculoventris (as subspecies of the nominal form). In addition to differences in coloration, we also observed some differences in ecoregional preferences that support the hypothesis proposed by HoLLIS (2006). In Paraguay, C. maculoventris has a strong affinity for the Dry Chaco (west of Paraguay River), whit some records in the Humid Chaco (Giraudo, 2001), whereas C. quadricarinatus is present in the Humid Chaco mainly near of the Paraguay River (CACCIALI et al., 2014). In fact, according to current distribution data, all four species in Paraguay would be allopatric, except perhaps $C$. bicarinatus with $C$. exoletus (Fig. 1). However, in other countries, many species of the genus (even those present in Paraguay) live in sympatry (Giraudo, 2001; Colli et al., 2002; Pinto et al., 2008), which makes us suppose that a more intense sampling effort could result in some observations of sympatry between 
Chironius species in Paraguay.

Chironius bicarinatus is the species that reaches the southernmost limit of the genus, being present in a variety of humid environments: from northern Bahía along the Atlantic coast, to Rio Grande do Sul in the Atlantic Forest in Brazil; in areas that border forested environments along the Uruguay River and in Cerro Largo Department in Uruguay (CARREIRA \& LOMBARDo, 2007; Carreira \& Maneyro, 2013); and acting as a common jungle dweller in Misiones (Argentina) (Giraudo, 2001), and also in Paraguay.

Chironius flavolineatus is a species inhabiting several different environments from dry habitats in Caatinga (Rodrigues, 2003), palm savannas in Bolivia, to Cerrado (Colli et al., 2002). In Paraguay, this species was only recorded in the Cerrado.

Finally, some pholidosis aspects are out of the previously known range in C. bicarinatus and C. maculoventris, according to data from Dixon et al. (1993), Giraudo (2001), and Carreira \& Maneyro (2013). Namely, the new ventral pholidosis range for females of C. bicarinatus is 154-170, and for C. maculoventris is $143-157$ for females and 154-161 for males. New subcaudal range have also been observed for males of $C$. maculoventris (90-125) and for females of $C$. quadricarinatus (91-123).

\section{Acknowledgement}

Mark Wilkinson (British Museum of Natural History) provided data on specimen BMNH 85.9.1.9. Arnaldo D. Cabrera (Museo Ambiental Itaipú), Andrea Weiler, Andrea Caballero (Colección Zoológica, Facultad de Ciencias Exactas y Naturales, Paraguay), Martha Motte, Ma. Teresa Flor- entín (Museo Nacional de Historia Natural del Paraguay), and Steve Gotte (United States National Museum), let us examine specimens under their care. Santiago Carreira (Serpentario-Instituto de Higiene, Uruguay) contributed with bibliographic support. Hillary Cirka reviewed an early version of the manuscript. We also thank the corrections and suggestions of the editor and two referees that helped to improve this work. The first author (PC) acknowledges Consejo Nacional de Ciencia y Tecnología (CONACYT - Paraguay) through the program PRONII for financial support.

\section{REFERENCES}

Aquino, A.L.; Sсотт, N.J. \& Мотте, M. (1996). Lista de anfibios y reptiles del Museo Nacional de Historia Natural del Paraguay (marzo 1980 - septiembre 1995), In O. Romero (ed.) Colecciones de Fauna y Flora del Museo Nacional de Historia Natural del Paraguay. Ministerio de Agricultura y Ganadería, Asunción, Paraguay, pp. 331-400.

Bertoni, A. de W. (1939). Catálogos sistemáticos de los vertebrados de Paraguay. Revista de la Sociedad Científica del Paraguay 4: 360.

Cacciali, P. (2009). Guía para la Identificación de 60 Serpientes del Paraguay. Asociación Guyra Paraguay, Asunción, Paraguay.

Cacciali, P.; Scott, N.; Aquino, A.L. \& Smith, P. (in press). Annotated taxonomic and distributional checklist of the reptiles of Paraguay. Occasional Papers of the Museum of Southwestern Biology.

Carreira, S. \& Lombardo, I. (2007). Chironius bicarinatus (Two-keeled Whipsnake). Uruguay, Dpto. Cerro Largo. Herpetological Review 38: 102.

Carreira, S. \& Maneyro, R. (2013). Guía de Reptiles del Uruguay. Ediciones de la Fuga, 
Montevideo, Uruguay.

Carreira, S.; Meneghel, M. \& Achaval, F. (2005). Reptiles de Uruguay. Universidad de la República, Montevideo, Uruguay.

CeI, J.M. (1993). Reptiles del Noroeste, Nordeste y Este de la Argentina. Series: Monografie, vol. 14. Museo Regionale di Scienze Naturali di Torino, Turin, Italy.

Chippaux, J.-P. (1986). Les Serpents de la Guyane Française. Series: Collection Faune Tropicale, vol. 27. Éditions de l'ORSTOM, Paris, France.

Colli, G.R.; Bastos, R.P. \& Araujo, A.F.B. (2002). The character and dynamics of the Cerrado herpetofauna, In P.S. Oliveira \& R.J. Marquis (eds.) The Cerrados of Brazil: Ecology and Natural History of a Neotropical Savana. Columbia University Press, New York, NY, USA, pp. 223-241.

Dinerstein, E.; Olson, D.M.; Graham, D.J.; Webster, A.L.; Primm, S.A.; Bookbinder, M.P. \& Ledec, G. (1995). Una Evaluación del Estado de Conservación de las Ecorregiones Terrestres de América Latina y el Caribe. Banco Mundial, Washington, DC, USA.

Dixon, J.R.; Wiest, J. \& CeI, J.M. (1993). Revision of the Neotropical snake genus Chironius Fitzinger (Serpentes, Colubridae). Series: Monografie, vol. 13. Museo Regionale di Scienze Naturali di Torino, Turin, Italy.

Dowling, H.G. (1951). A proposed standard system of counting ventrals in snakes. British Journal of Herpetology 1: 97-99.

Fitzinger, L.I. (1826). Neue Classification der Reptilien nach ihren Natürlichen Verwandschaften nebst einer Verwandschafts Tafel und einem Verzeichnisse der Reptilien Sammlung des K. K. Zoologischen Museum's $z$ u Wien. J. G. Heubner, Vienna, Asutria.

Giraudo, A. (2001). Serpientes de la Selva Paranaense y del Chaco Húmedo. Literature of Latin América, Buenos Aires, Argentina.

Giraudo, A. \& Contreras, A.O. (1994). Lista preliminar de los reptiles registrados en el Departamento de Ñeembucu, Paraguay. Boletín de la Asociación Herpetológica Argen- tina 10: 1-4.

Hollis, J.L. (2006). Phylogenetics of the genus Chironius Fitzinger, 1826 (Serpentes, Colubridae) based on morphology. Herpetologica 62: 435-453.

Kок, P.J.R. (2010). A new species of Chironius Fitzinger, 1826 (Squamata: Colubridae) from the Pantepui region, northeastern South America. Zootaxa 2611: 31-44.

Linnaeus, C. (1758). Systema Naturae per Regna Tria Naturae, Secundum Classes, Ordines, Genera, Species, cum Characteribus, Differentiis, Synonymis, Locis. Tomus I, Editio Decima, Reformata. Laurentii Salvii, Stockholm, Sweden.

Marques, O.A.V. \& Sazima, I. (2003). Ontogenetic color changes may strengthen suggestion about systematic affinities between two species of Chironius (Serpentes, Colubridae). Phyllomedusa 2: 65-67.

Marques, O.A.V.; Eterovic, A. \& Endo, W. (2000). Seasonal activity of snakes in the Atlantic forest in southeastern Brazil. Amphibia-Reptilia 22: 103-111.

Martins, M.; Marques, O.A.V. \& Sazima, I. (2008). How to be arboreal and diurnal and still stay alive: microhabitat use, time of activity, and defense in Neotropical forest snakes. South American Journal of Herpetology 3: 58-67.

Motte, M.; Cacciali, P.; Aquino, A.L. \& YANosky, A. (2004). Anfibios y reptiles de los humedales de Paraguay, In D. SalasDueñas, F. Mereles \& A. Yanosky (eds.) Humedales de Paraguay. Comité Nacional de Humedales, Asunción, Paraguay, pp. 167174.

Palmuti, C.F. de S.; Cassimiro, J.; \& BertoluCI, J. (2009). Food habits of snakes from the RPPN Feliciano Miguel Abdala, an Atlantic Forest fragment of southeastern Brazil. Biota Neotropical 9: 263-269.

Pinto, R.R.; Fernandes. R.; \& Marques, O.A.V. (2008). Morphology and diet of two sympatric colubrid snakes, Chironius 
flavolineatus and Chironius quadricarinatus (Serpentes: Colubridae). Amphibia-Reptilia 29: 149-160.

Rodrigues, M.T. (2003). Herpetofauna da Caatinga, In I.R. Leal, M. Tabarelli \& J.M.C. da Silva (eds.) Ecologia e Conservação da Caatinga. Universidad Federal de Pernambuco, Recife, Brazil, pp. 181-236.

Strussmann, C. \& Sazima, I. (1993). The snake assemblage of the Pantanal at Poconé, western Brazil: faunal composition and ecological summary. Studies on Neotropical Fauna and Environment 28: 157-168.

Tipton, B.L. (2005). Snakes of the Americas.
Checklist and Lexicon. Krieger Publishing, Malabar, FL, USA.

Yanosky, A.A.; Dixon, J.R.; \& Mercolli, C. (1996). Ecology of the snake community at El Bagual Ecological Reserve, northeastern Argentina. Herpetological Natural History 4: 97-110.

Ziegler, T.; Unger, J.; Feiler, A. \& Lehr, E. (2002). The first Gran Chaco expedition of the Museum für Tierkunde Dresden: Records of amphibians, reptiles and mammals from the Dry Chaco of Paraguay (Amphibia, Reptilia, Mammalia). Faunistische Abhandlungen 23: 219-238. 